\title{
The roaring silence of the Amazonian General Language in printed material \\ from the 19th century: a design study
}

\author{
Rômulo do Nascimento Pereira, \\ Ligia Maria Sampaio de Medeiros
}

\section{FIRST AND FOREMOST}

The paper presented herein is part of a greater, ongoing study that researches the beginning of the printing activity in the State of Amazonas. By observing further the complex relations that constitute the artifacts printed in the Amazon, we arrived at the Amazonian General Language [LGA]. Alive to this day, and modernly called Nheengatu (good language). Starting from its narrative, we aim to observe the use of graphics technology in a project for dominion and control over a vast territory in order to turn it more legible or less crude, certainly not for everyone. This way, we try to read the printed communication and the design, more extensively, backed up not only by material artifacts but by the history of a location marked by disputes and a world perspective set in the treatment of others. The various peoples that inhabited the region made their own reading of this world, interacted with it and its mysteries using their language, knowledge and technology. Although we insist in perceiving them as an indistinct and gentle mass named the Indian. Maybe not so distant from the perception of the European conquerors, who saw human beings as goods or workforce at their disposal, and so used them, just like those others with black skin from the other side of the Atlantic. Both suffered extreme violence, were enslaved to keep the privileges and wealth of so-called civilized white men.

The methodological set proposed for this research feeds on bibliographic sources, especially on the dissertation of José R. Bessa Freire. On the settlement of landmarks and the contact with players of a narrative ought to be critical. It was also used references from the design field, among others. In the Hemeroteca Digital [Digital Newspaper Library] of Biblioteca Nacional [Brazilian National Library], in Rio de Janeiro, we gathered information from primary sources, in the Exposições, Fallas e Relatórios [Expositions, Speeches and Reports] from the Province of Amazonas and in two journals, one from Belém and the other from Manaus, both from the 19th century. Some notes were extracted from the Dicio- 
nário Topográfico, Histórico, Descritivo da Comarca do Alto Amazonas [Topographic, Historical and Descriptive Dictionary of the District of Alto Amazonas] of Lourenço Amazonas, an important private publication edited in 1852. The Exposições [Expositions] or Fallas [Speeches] were publications in which a ruler, or someone at their service, rendered an account of the Province's trades and informed about the taken steps. In all these publications, the majority of the texts had the governor informing the Province's Legislative Assembly about the actions taken in the year, with different data and reports on the general situation. Both fronts, references, and sources, dialogue in exploratory research which aims to reflexively map the uses that an Amazonian language found, its conflicts and printed culture is still little known in the design field.

The critical observations are made in a very distant place in time from the events and characters mentioned, but with remaining notable presence in today's power relations and treatment to indigenous peoples and others. Thus, by covering printed technology in the mid-19th century, we may read more than a civilization project far from being linear and clear:

Starting from this hybrid place in cultural value - transnationalism as the translation - the postcolonial intellectual tries to elaborate on a historical and literary project. I am increasingly convinced that the clashes and negotiations of differential meanings and values in the inside of "colonial" context, their governmental speeches and cultural practices anticipated, "avant la lettre", several issues on meaning and judgment that have become common in contemporary theory - aporia, ambivalence, uncertainty, discursive ending, agency's threat, intentionality, synthesizing concepts, to name a few examples (Bhabha, 1998, p. 242).

Buchanan (2009, p. 409), while introducing the foundation of research in design, states that: "The common subject matter of design is variously described as the artificial or the human-made or products that support human beings in all of their individual and collective activities." Hence, when speaking of LGA, we stress that it will not be observed in an isolated form or as a simple index of the increase of Eurocentric artifacts in the untouched nature. We seek, even in a nutshell, perceive the overlapping of territories, including the political and economic, present in deviations, in the practices that led to the flood period, then the containment attempt and the forced drought of a language. Although we draw a comparison with the great river's movement (full and low tide), this process was neither natural nor linear. It was a plan, a project of a European monarchy and of varied interests which played with lives, whether directly or with indifference, of a large human contingent in the distant and vast land of amazons. 
Bonsiepe, while speaking of democracy as a space to reduce heteronomy, stresses the utopian aspect of project activity (2011, p. 21), not without noticing its contradictions. Moreover, says that his intention, shared in this paper, is to "form a critical awareness before the enormous imbalance between the power centers and those subjected to them." We then propose to hear an indigenous language, observe both its printed and invisible marks in order to describe and reflect over the unknown path of this way to give meaning to the world, the language, and its developments in a vast region of Brazil. Burke (1995, p. 40-41) speaks of the deceptive passive appearance of language in society and tells us that "speaking" is:

a way of making, the language is an active force in society, a means through which individuals and groups control other groups or resist this control, a means of changing society or holding back the change, to affirm or suppress cultural identities.

From this arises our interest, from the force vector that a language has to act over the reality of the place we call today the Amazon, before a sizeable disputed area by various European powers. To begin the conquest, a language was elected to be taught compulsorily, and it was one of the most spoken in the coast of brazilwood's land. It was required to be in written form and reproduced by the existing graphics technology in printed forms. With this operation, the record that was oral before becomes fixed on paper, speaking gains a concrete configuration from the conventions of writing and the language loses its fluidity and turns into glyphs, types, syllables, words that seek to represent the world. Asa Brigs and Peter Burke (2006, p. 13-14) recognize an expansion of the concept of communication and suggest that, regardless the space or time from which it is investigated, researchers on communication and cultural studies: "should take into consideration history; and that historians - of any period or tendency - must take seriously into account communication theory and technology." Even in so-called recent events, it is present a tradition or clear connection with the past.

We propose in this study an investigation where various fields of knowledge are discussed, not very worried in delimiting borders, seeking to encounter and transit with the knowledge of the other. During this journey, we make speculative and critical observations, not for lacking objectiveness, but for it being a form of suspicion of the own scientific speech of natural sciences, often used as the only model of research. The impartiality, or rather the claim of a naked eye of culture or intentions does not accompany us, because we often show curiosity to understand the place of living better and with which one interacts on a daily basis. Therefore this article is also a speech that intends to stimulate qualified exchanges and raise some questions to reach an awareness of the place where we are and how it was constituted. 
The speech, as said by Flusser (2007, p. 89), is not produced by "natural sounds, like, for instance, in the singing of birds, and writing is not a natural gesture like the dancing of bees." That is why communication is not a natural science, leading to a domain of artifice, of common codes and culture. Communication has the essential function of accumulating acquired information (Flusser, 2007, p. 93) by the form of a common code, and of moving us away from the senselessness and death. Now the typography is intimately linked to the 'solid form of language' - the writing, as defined by Bringhurst (2005, p. 9), in his precise, poetic style. The author makes an unusual association of languages to liquids or fluids, an analogy used in this text. Holding, or somewhat solidifying this brief form is what seeks the writing and, by extension, the typography. He also reinforces similarities and especially fundamental differences between language, writing and typography: "the manuscript and typography world demands artificial support - an organized training of youngsters, in other words, a school while spoken languages maintain themselves and blossom in any place where there are human beings" (Bringhurst, 2005, p. 15).

In the vast territory of the Brazilian Amazon, the waves, or rather the pororoca $^{1}$, a wave of native languages has been smoothed out by the imposition of one based on Old Tupi. Language adapts and flows through various paths; printed communication, in turn, fixes in time a voice, a piece of information according to a plan fit to the technology used to produce artifacts. The process of printing on paper, on the other hand, was forbidden in Brazilian colony at the time LGA was being imposed in the region. The initiative of António Isidoro in Rio de Janeiro, in 1747, was interdicted as soon as the Portuguese Court recognized it. The common language would have taken the same path, the ban, although its simple expulsion was not possible, as occurred to the Portuguese printer. For it is not possible to detain by force or completely dry out a large river, or rather a broadly used language. This continued to flow in veins, memories, names and also in History.

1 In the Dicionário of Lourenço Amazonas (1852, p. 54), when he describes the Amazonas River, he registers the phenomenon that locals call pororoca. This happens when, in certain times of the year, the waters of a river encounter the ocean provoking strong waves that bring down trees and marginal land, besides making a great roaring. The phenomenon also occurs with other Amazonas' affluents in the region. In 2005 it was recorded the extinction of the phenomenon in the Araguari River, in Amapá, probably as a result of human action. 


\section{MISMATCH OF WATERS}

While writing in the 21 st century using a computer keyboard, we may easily stop noticing with clarity this sophisticated system - the language. In Brazil, we use the Portuguese language, which arrived in a vast territory inhabited by other humans, diverse to one another. They were not perceived as equals by travelers, being wrongly identified as inhabitants of the Indies, therefore being tagged as Indians. Many were the misunderstandings, mismatches and mixtures in a conflict that occurred in several stages, including in communication, and on both sides. The native peoples had to name a foreigner with fairer skin and beard, and they made it according to their references. In addition to all the artifacts never seen before, garments, weapons, mirrors and other objects had to be translated and suitable, not without surprise or inaccuracies. Certainly not without interests. Moreover, as it happens in the disputes, the winner imposed charges on the losers.

The Amazonian indigenous people were an unwritten society, their control over the world they inhabited was through the people's speech, myths, knowledge, traditions, technology, and culture, not that fragile or weak as we are prone to believe. This process of inserting a specific meaning into a word and sharing it with a group of people should not be taken lightly. Also, it was made by at least 700 different forms in the Amazon (Freire, 2007, p. 13) and over a thousand in Brazil (Rodrigues, 2005). Among several indigenous languages, the study of Old Tupi was privileged, both by the Portuguese and the French, for many people of the Brazilian coast spoke it. Old Tupi was the origin of the two Brazilian general languages: Paulista or Meridional, and the Amazonian. Similar procedure occurred in Spanish America with the "lenguas generales" in Mexico, with Náhuatl; Quechua in Peru and Guarani in Paraguayan territory. To carry out the conquest and colonization of the discovered lands, to be familiar and to explore indigenous wealth, the bases for a more accurate communication had to be implemented. The project and implementation of a native language was a privileged instrument for this, and its history, such as the Amazon region's, is prodigal of contradictions and violence.

In the 17 th century, in addition to Portuguese settlers, many of them being criminals punished and exiled in Brazil, the missionaries, especially Carmelites, Capuchins, and Jesuits, were other major players. These were employees paid by the Portuguese Court (Freire, 1994, p. 32) and while compulsorily converting the natives into the Catholic religion, they also promoted the "conversion" of these to the current economic system, in the form of goods. The missionaries promoted expeditions called "descimentos" [downward slope], in which they convinced the Indians to leave their villages and go live in the city villages. After being split up 
in villages, they were divided among settlers, missionaries, and services of the Portuguese Court. There were two alternative ways of capturing Indians: the "rescue," in which the Portuguese exchanged goods for Indians captured by other Indians allies of Europeans. Promoting the so-called "just wars," in which armed military groups invaded territories of so-called hostile Indians to capture a great amount of them, including women and children (Freire, 1994, p. 29-30). Hence the villages and small towns were formed, where the Indians learned the General Language, along with many other "civilized" customs, a religion that did not welcome them equally, and an inhuman work exploitation system and many other lessons.

The conflict of interest between settlers and missionaries for the control of the indigenous peoples has become continuous during the colonial period in the Amazon, with riots and many turnarounds. For seven decades, starting from 1686, missionaries obtained authority over Indians, being $20 \%$ destined to the Court. From then on, any expedition (downfall, rescue or just war) would only be done with the consent of a board and monitoring of religious men (Garcia, 2005, p. 52). Added to this tension, there was the resistance of native peoples, some tribes ended up merging to fight the mighty enemy in ordinary which exterminated them and turned them captive, including their children. Freire (1994, p. 34) questions the idea of the occupation of the Amazon in the Colonial Period. According to him, the most concrete would be to speak of a process of depopulation or a catastrophe. So remember that this narrative was written from the perspective of conquerors, missionaries, and Portuguese settlers:

Silenced the Indians, the Portuguese retakes the floor. The first draft of the history of the Amazon is by Bernardo Berrado, a "horse captain" of Portuguese nationality, and governor of the State of Maranhão and Grão-Pará (1718-1722). With free access to official archives, governor Berredo turned into a historian and wrote a chronology of events. As part of the archives consulted by him was lost, Berredo became a primary source of colonial history (Freire, 1994, p. 36).

Under the title “Annaes históricos do estado do Maranhão," this Berredo's book was published in Lisbon in 1749, one year after his death. What did not perish was the uncritical vision of the region's history, written without clearly reporting the genocide that the colonization plan involved, and not trying the least to change the point of view. The defeated, the expatriates in their land that did not have their names or tragedies duly registered, what would they say if they had the opportunity of writing in general language their vision of this story? We will never know. What does not prevent us from questioning or changing the direc- 
tion of the axis in which the narratives about the region are produced, and several researchers have conducted this. Speaking, not without some discomfort starting from this purebred son, of the modernity with the industrialization that is the design. For this, we broadened our interest range by electing as an object of study, instead of the artifact/product, its project or production. However, a brief narrative about a language linked to relationships, disputes, and gaming representations and that are, materialized or silenced in many ways in speech and also printed material.

In "Dicionário Topográfico, Histórico, Descritivo da Comarca do Alto Amazonas" by Lourenço Amazonas ${ }^{2}$, published in 1852 in Recife, we find many occurrences of the term "lingoa geral" [general language], also named in the edition as "tupica" [Tupi language]. We do not have as a purpose the analysis of the Amazonas discourse, and we only want to notice the occurrence and treatment given to the LGA in its printed discourse and remove data of interest. His work was produced as an extensive dictionary, a book that gathers definitions and information, constituting an index and also an important source for the study of the region. In addition to the selection of entries described by the author, he gives accounts and makes critical comments about the work. It is important to say that, although Manaus already had a print shop, this dictionary was produced in Recife, surely because the Amazonas print shop was too modest to carry out this project, besides having all the material be at the service of the government. The work's title brings the term "comarca" [district] of Amazonas because it was produced before the location was turned into a province. The author could have altered the information but decided not to. In the prologue, he explains that he intended to show how a comarca works, as everyone already knows the form of organization of a province (Costa, 2016).

Lourenço Amazonas (1852, p. 142-165), in the entry "Indios" [Indians], after saying that it is an improper term to designate natives, describes them and criticizes the opinions on them. For instance, he regrets that "Europeans, with the discovery of the Americas, only wanted to estimate in the indigenous the ability to serve, considering them more as barbarians than as slaves." Later he reports that each indigenous nation speaks its dialect, very different from one other. Nevertheless, every nation that relates to Christian institutions speak the General Language or Tupi. He continues to try to find terms and stories that describe what an Indian is, after many different definitions, including ecclesiastical, wor-

2 The author served in the Amazon, on behalf of the Imperial Navy and is also the author of the 1857 romance novel Simá - a historical romance novel of the upper Amazonas. 
ried if these beings had a soul or not. To a certain point, Lourenço Amazonas (1852, p. 154) speaks of work relations in Amazonas as having a tendency: "undoubtedly concerning the services practiced by Indians, what slavery seems to lack is only the name." He continues some observations on the Indian:

Hence oppressed and demoralized, it is observed in them distrust and animosity. Their somber face instead of joyful, as if natural for them, seldom is expressed satisfactorily, except their work result, which they take seriously; but if someone addressed them kindly, especially if speaking in the General Language (which they see as being on the same level), that clouded face winds up expanding; their cheering expression is more perceptible by the still convulsed movements of their muscles, and their chest is relieved from an afflicting and heartrending oppression. In this expression, it is, like before one's eyes, the Indian's heart, in all its naiveness.

The Dicionário... by Lourenço da Silva Araújo Amazonas, has an entry for "Lingoa Geral" with a wide array of information divided into three pages, the edition registers various names of indigenous origin. It is proof of the power of native languages that render meaning to the vast Amazonian world, creating a repertoire suitable to allow translation and dialogue with this universe. The second to last word registered in the dictionary by Amazonas (1852, p. 363) was "Yurú-quiá: name with which the Indians gracefully call the Madeira River, alluding to the great amount of floating wood and islands that often block its mouth.”

These Amazon inhabitants acquired the LGA, as they are forced to inhabit the villages. In these places, settlers, missionaries, slaves and mestizos, everybody was drenched by Tupi language. In the 1866 report, discussing the "Directorias de Índios da Província do Amazonas" [Board of Indians of the Province of Amazonas], there is information of them being 38, inhabited by 17.386 Indians, of diverse nations or tribes. Also, it states: "each of them speaks their special dialect; but almost all of them also speak the General Language, which is of the Tupis, or Tupinambás." Hence, the Portuguese Amazon was led to bilingualism, not without confrontations and mixed feelings. Moreover, we could remember that a language has a fundamental role in the "social construction of reality," it creates or "constructs" society such as it is constituted by society (Burke, 1995, p. 42).

In the Amazonian region, one of the protagonists in the architectural, social space was, for a long time, a native speaker, although following a plan outlined in Portuguese. The Nheengatu: "while substituting various indigenous languages, broke away from the oral tradition and did not constitute a written means to communicate previous experiences to new generations, despite being equipped 
with an alphabet by the Jesuits" (Freire, 1994, p. 35). The adoption of the LGA marked a crack, bending severed ties by compulsorily choosing a single speech, turning it into a burden or prison. Speaking of LGA, everyone affirmed the domination of the foreigner by the imposed artifice, a form of cultural colonization of these people, so different from each other, compelled to carry out orders received in the General Language promptly.

This journey was especially tricky for groups unfamiliar with Tupi, being every day the use of physical punishments in that period. There are accounts of a greater refusal among women in waving their native tongue for the other imposed language. Thus leading them to be "beaten by the missionary, responsible for the school, with a spanking paddle, until their hands were swollen and bleeding" (Daniel apud Freire, 2003, p. 52). We cannot fail to observe the constant presence of this other language, the violence, fluently used in the different relationships established between existing cultures and the other seeking a full domination and control.

After its diffusion and appropriation by a broad native population, the LGA started to be seen exclusively as a language of Indians, as opposed to the Portuguese, less and less spoken, even by the colonizers. There was no equivalent fluency in another type of human origin: the movable types. In the bibliography produced in the General Language, there is a predominance of grammar, vocabulary, dictionaries, catechisms, sermons, and prayers (Freire, 2003, p. 19), although there are also outnumbered, records of narratives, songs, and myths in General Language and other native languages. This predominance of works for utility nor pedagogical purposes may be observed in the long title stamped on work's cover sheet: "Diccionario portuguez, e brasiliano, obra necessaria aos ministros do altar, Que emprehenderem a conversaõ de tantos milhares de Almas que ainda de achaõ dispersas pelos vastos certões do Brasil, Sem o lume da Fé, e Baptismo (...)" [Portuguese and Brazilian Dictionary, necessary work for the ministers of the altar, which undertook the conversion of so many thousands of souls that are still dispersed in the vast hinterlands of Brazil, without the light of faith, and baptism (...)]. The work by anonymous authorship, published in Lisbon, in the year 1796. Until the beginning of the 19th century, all these works were printed outside the Brazilian colony, as it was banned by the Portuguese Court the installation of industries within the Brazilian colony, as established in the 1785 Charter.

The LGA expansion occurred with the sponsorship of the Portuguese Court, a strategy, among others, to make the natives kinder before being livid and the vast, mysterious territory clearer. The constant conflict between religious orders settled in the region and the interests of the settlers and the government stays alive. It indeed was not a dispute for souls, but for the principal wealth found in 
the region: a massive contingent of people or, in European view, overwhelming native workforce available to cater their interests. This dispute will be solved in the 18th century, when Portugal, under the political command of then the Prime Minister and future Marquis of Pombal, take a series of measures, including the expulsion of the Jesuits of their domain and one that profoundly affected the overview of the region, the Indian Directory. Through this law, the Portuguese Crown diminished the role of the Church by granting power over the Indians to the Directors, also made a series of injunctions, among which banned the use of native languages and General Language. The Indians could not even live collectively, being forced to adopt a lifestyle reputed as decent or superior to theirs. The Directorate oriented the production system to which these 13-to-60-year-old Indians were subjected, which included the payment of tithes on all they produced, duly charged by the Directors, who had all the power to dispose of them (Freire, 1994, p. 58-59). To keep the region on a shorter leash, Pombal also appointed his brother as the Governor of Grão-Pará and Maranhão.

Under the law, the LGA started to be put aside, and a silencing narrative that was noisily present, such as in forced changes of many indigenous names of villages and towns more "decent" ones, that is to say, Christians and Portuguese. This way, with the strength of the name in the Portuguese language, they tried to reinforce a loose structure, and that in the 19th century was indeed tightened, until almost silencing the speech that was imposed before. Thus the other side of this coin was set and began a period when bilingualism no longer mattered, the domains, wealth and exploration were assured:

During the whole colonial period, however, the Portuguese Language, with categories that did not bring intelligibility to the cultural and ecological reality of the region, remained a minority, as an exclusive language of the administration, but not of the population. This situation only changed during the second half of the 19th century, when monolingualism started to prevail in a European language. (Freire, 2003, p. 13).

\section{A GOOD LANGUAGE AND ITS PRINTED MARKS}

The beginning of the 19th century watches the disembarking of the Portuguese Court in Rio de Janeiro fleeing from Napoleon, coming with it the first print shop in 1808, and the origin of Imprensa Régia [Royal Press]. In the same year, navigation in ports is allowed to friend nations, facilitating commerce, which does not occur in the Amazonas River, which remained closed until 1866. The impediment to industrial activities is also abolished, among other measures, thus the first private typographic office started its activities in 1811 in Bahia, and in Belém of Pará in 1820. The Portuguese elite was unhappy with the departure of 
the Portuguese Court, the loss of commercial monopoly of products of the Brazilian colony, leveled to the category of Kingdom in 1815, and by the English domination over Portugal, among others. To some degree, the Portuguese citizens living in the Old Continent felt the bitter taste of being colonized, certainly in far milder than what happened on the other side of the Atlantic, but they did not like the taste at all. They revolted, and in 1820, the Liberal Revolution broke out demanding the return of the court, which indeed happened with the return of the Royal Family and the court.

However, this liberal movement longed for an uncomfortable return: the return of Brazil to the status of a colony, providing them, as before, with the sweet taste of wealth.

Nevertheless, in 1822 Brazil becomes independent, having as emperor Dom Pedro I, son of Dom John VI of Portugal ${ }^{3}$. Part of the tensions and struggles that took place in different places within the kingdom remained and resulted in a significant conflict in the Amazon region, the elites wanted to maintain their bond with Portugal and fought against the independence, in spite of this they were forced to accept no freedom, but another domain aloof to the interests of the region. Part of the strain remained and led to a massive dispute within the region directly echoing in the weakening of the use of the LGA. The containment and brutal repression of the popular uprising of Cabanagem (1835-40) contributed to the decrease of the LGA speakers. Another war, but in a distant place, in Paraguay (1864), in which soldiers from the Amazon were led to fight, some against their will, against other speakers of a general language similar to the one they had learned.

The process of exclusion followed a sort of banishment imposed on the native, who "did have no more nationality nor own language, taking on the status of generic Indian or tapuio" (Freire, 2003, p. 172). They did not lose just their mother tongue, but also their identity and memory, different from the gentle Indian that maintained their connection with a group or community.

The tapuios were adrift, drowning in waters that were not theirs, and while they were not dead, they were forced to work so that others navigated calmly. A story that, with different shades and characters, is still repeated today, not only in the Amazon. The entry about the city of Manaus (N. S. da Conceição de Manáos) in the Dicionário... describes the capital of Amazonas as having three neighborhoods: São Vicente, of the Matriz (Downtown) and of Remedios, in addition to a square, two churches and 16 streets. Its origin occurred, according to the author, with the "enactment of some families of Barés, Banibas and Passés under

3 However, in order to have its independence recognized by the former colonizers, the Empire of Brazil was forced to pay massive compensation to the Kingdom of Portugal. 
the auspices of the Fort of São José do Rio Negro", along with descendants of other native people.

The text also registers the distribution of its inhabitants: 900 white people, 2.500 mamelucos [sons of Indian women and Portuguese men], 4.080 Indians, 640 mestizos and 380 slaves; all in "900 fairly disperse dwellings." It still reports that the city inhabitants dressed seriously and the women with "taste and luxury, enhanced by natural and superior grace." Moreover, continues: "They speak Portuguese very well, although they also use the General Language a lot. Spending part of the day in baths, which the neatness becomes their an innate quality" (Amazonas, 1852, p. 187-190). Although it was not registered in the entry, the first typographic office in Amazonas started working in 1851, satisfying the diverse demands of local government.

In this small location, it was created the Estabelecimento dos Educandos Artífices [Handicraft Apprentices Establishment] in 1856, although it started working two years later as an institution to host orphans, destitute and indigenous children in order to provide them with education in the official language and the learning of trades. In Pará, a similar house was founded in 1840. In practice, there was a concern about preventing these children from "becoming useless or even dangerous to society", in other words, a form of social control by disciplining and teaching a profession to the children of the working class. We must add that it's not always the parents choice, as many indigenous youngsters were removed from their homes in the interior of the province so as to receive education in the Educandos, and thus create a "common bond between the civilized race and the savages' tribes” (Rizzini, 2002, p. 2-4). The compulsory education of the first Portuguese letters was another front against the General Language, not always with the expected success.

The report produced by the poet Gonçalves Dias in charge of the government of the Province of Amazonas, in 1861, certifies to the often precarious state of education, especially in communities in the province's small town. In spite of that, he recommends that mandatory education in Portuguese continue, because: "the advantage of school attendance is mainly, so they become unaccustomed to using the General Language, always spoken at home and on the streets, and everywhere else" (Dias, 2002, p. 16). Eleven years later, in an 1872 report, in the section on public education in Amazonas, we read that education would have as its main purpose "the customs, repression of bad instincts, and the development of noble qualities of the heart...”. These citations are enlightening, reinforcing the idea not of instruction, but of repression to a speech considered inferior, as well as the fight against native customs, seen as unworthy. Although it is curious to guess what these referred noble qualities would be, maybe subservience or gentle ignorance. 
We may also observe this attempt to control and marginalize the writing and printed communication, by focusing the complete predominance of the Portuguese Language in these forms, even though the LGA had full control of everyday speech. A perverse and calculated mismatch to not fix on paper the language of the streets, the voice of the exploited and an unwanted presence, all translated in a roaring silence. In this designed muteness of blank spaces, we try to read what has not been expressed in the journals, and official and private editions. This way, we seek in the Hemeroteca Digital of Biblioteca Nacional in Rio de Janeiro the occurrence of the expression of the general language or "lingoa geral" in two journals of the Amazonian region and in Exposições of the government of Amazonas, from 1851 to 1888 , in order to empirically verify the use of the LGA in printed format. Even though restricted, this research revealed valuable information, not only numerically due to the low quantity of occurrences observed, but especially for the reading of a place denied to the other, language and human being.

This clipping made of brief speeches in which a language was printed and read in printed artifacts of the region helps us ponder the tortuous path crossed by an imposed language, which later achieved the fluency in oral communication and was pushed, swept to the border of both cities and printed material, and the society that had adopted it. We also observed its difficult disposal, but how do you silence a language? Cutting it off? Certainly maiming and articulating the violence of different and very 'civilized' forms, and so it was done.

In the long entry in the Dicionário... about the Negro River, when referring to the government of the Rio Negro Captaincy, in charge of the Brazilian Navy Captain José Joaquim Victório da Costa, in 1806, Lourenço Amazonas (1852, p. 263-264) said that the governor was very much contradicted in his administration by the Captaincy Ombudsman.

Perhaps that is why he "worked very hard on managing his interests." It is also stated that during his administration, it increased the oppression over indigenous people, some being forced to work in chains and miserable conditions. This ruler, in addition to the use of violence, became famous for the vast command of the General Language: "which he appropriated with so much joy that he corrected even the indigenous people."

The noble governor must have noticed the need for also having the general language in his possession, thus more accurately have the lands, resources, and souls under his responsibility, his administration ends with the inauguration of the new governor in 1818 .

In the section "Public Tranquility," of Falla... of October 1, 1853, published in Manaus, among other news, it is narrated the conflict that happened between 
the Araras Indians and other Indians settled near the Sapucaia-oroca village, the interior of Amazonas. An indigenous woman was imprisoned and sent to the capital. The text is signed by the President of the Province - Councilman Herculano Ferreira Penna, who describes the woman: "This poor creature, vivid image of stupidity and imbecility, did not provide any clarification that I wanted to obtain." Also, continues to describe the lack of communication with the indigenous woman: "for being incapable of understanding any question that was addressed in the General Language, or with gestures." In the same Falla, in the section "Public Education," it is suggested the creation of a General Language chair, as "a means of facilitating and strengthening our relationships with the indigenous people and promoting catechesis." Showing an ambiguous position in relations to the LGA, in which even being fought and marginalized, authorities recognized that the domination over the region depended on its mediation. Nevertheless, they did not allow him to be put in a subordinate position, demeaning her as a captive, such as the indigenous woman turned prisoner.

In the journal "Treze de Maio", published in Belém by Typographia de Santos and Irmãos, we found four occurrences of "lingoa" or general language in digital copies in Hemeroteca Digital, from 1845 to 1861 (Figure 1). In the section "Diverse Notices", in the October 13, 1855 edition, just below an advertisement of fine chocolates, there is another with a typographic vignette showing a black man holding a cane and looking back. It is an advertisement stating the escape of "a mulatto slave" named Geraldo. His owner José da Silva Castro adds various physical characteristics and says that Geraldo was a "son of Amazonas, speaks General Language and was initially Marcos Cohim's slave, and later of José Joaquim Ramos Villar of whom the advertiser bought”. In the August 10, 1861 edition of the same newspaper, in the section "Advertising", there is a reference of the sale of a number of editions by José Maria da Silva's bookstore, including the Diccionario da lingua geral dos Indios no Brasil [Brazilian Indians' General Language Dictionary], by João Joaquim da Silva Guimarães. Hence an occurrence indicated the domination of General Language by a human being turned slave, and the other showed a printed artifact used for learning/teaching it. The other two occurrences were repetitions of these advertisements, each one just one time. 

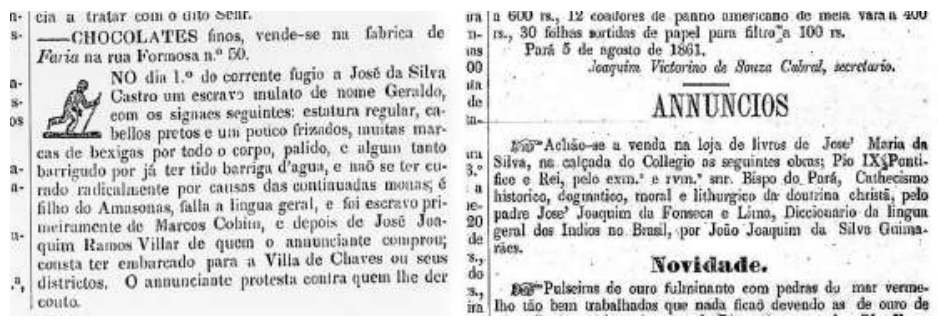

Figure 1: In the newspaper Treze de Maio, edited in Pará, two interesting references to LGA: on the right, a notice of the escape of the slave Geraldo in 1855, fluent in the LGA; on the left, a bookstore advertisement in 1861, with the sale indication of a dictionary of the general language of the Indians in Brazil (used with permission of the Biblioteca Nacional).

The first journal of the capital of the Province of Amazonas was the 5 de Setembro, later renamed Estrella do Amazonas [Amazonas Star]. This was for a long time the only journal printed in this Province. Among almost five hundred digitized copies of Estrella, from 1854 to 1863, we found only three occurrences of general language or "lingoa geral". One of that described an indigenous woman and an old indigenous man who "spoke something in general language". The other one referring to a type of turtle that "is called in general language sararacas, which means something that comes apart". The third, and the most revealing, of April 30, 1856 (Figure 2), in the section "Avizos Diversos" [Diverse Notices $]^{4}$, we see in the fourth paragraph a typographic vignette of a black-skinned man walking holding a bundle, indicating the escape of a slave. Another similar vignette, but in the feminine gender, brings another record of the escape of a woman turned slave. In these notices, as describing João Mulato "(taking more after a tapuio)", it is said that he is "around 34 years old", continuing describing João as not having his upper teeth, "except his front teeth, little beard, and gaunt face, bearing the word 'slave' written in general language from the time he was a slave of Lieutenant-Colonel Cordeiro from Rio Negro". Also, it continues: "not too talkative, except when drunk, of medium height, and well-known in the re-

4 The text preceding this section is titled "Necrology," which registers in seven paragraphs the death of a city's notary public. In the following notices section, we read a note reporting the completion of an inventory of the citizen's goods. Later on, an advertisement of the store Bazar Amazonense, indicating the sale of fine fabric and others, including locks, blank books, catechisms, booklets, cheese, lard, and chocolate, among others. A little typographic vignette with a vessel advertises the sale of a boat and then the advertisement of the escaped slave. 
ferred river.” João had escaped with Alexandrina, of the same owner, Antonio Jozé Pereira Carneiro, from the city of Pará; the second notice refers to her.
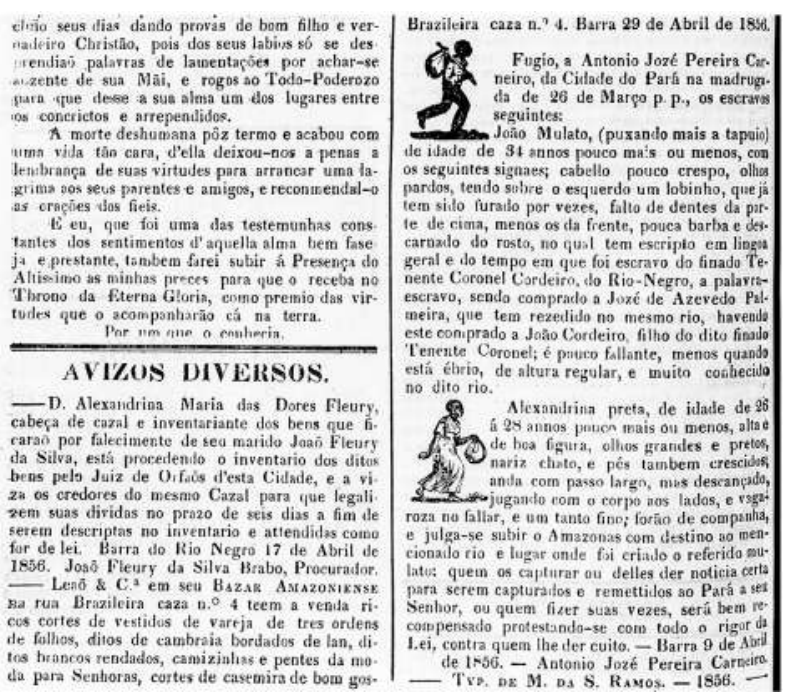

Figure 2: Detail of the last page of Estrella do Amazonas, of April 30, 1856. On the right, the notice of the escape of the slave João Mulato (used with permission of the Biblioteca Nacional).

The reading of this revealing advertisement also served the researcher Patrícia Sampaio, who, in her article on Slavery in Manaus in the 19th century (2002), tells us how to write the word 'slave' in Nheengatu: 'miaçua'. Six letters carved in the flesh to expose their status to everyone. The slavery of black-skinned people had a reduced economic importance in the Amazon as compared to the Northeastern and Southeastern Brazil; even so, it must be remembered and discussed so as not to become invisible as well. The disappearance process is not exclusive to the LGA. In the Province of Amazonas, since the decade of 1866, it was saved the amount of ten contos de réis per year to conduct the freeing of slaves, especially children (Sampaio, 2002, p. 18). In this province, the abolition of slavery occurred in 1884, therefore, four years before the signature of Lei Áurea [Golden Law], which did the same throughout the Brazilian territory in 1888.

On May 22, 1858 edition of Estrella do Amazonas we find the sequel of this story, again published in the Avizos Diversos ${ }^{5}$ Section. At first, we have an adver-

5 On the left column of the newspaper's last page where the notices section is comprised, we read the ending of a text entitled "Interessante e Sentimental" [Interesting and Sentimental]. It is described a singer performing in a festivity in France, after chanting 
tisement of a store that claims to have a great variety of fabric, some French of "the most modern tastes." Following in the same section an advertisement for a house rental, and then we see the same image of the previous advertisement: a typographic vignette showing the escape of a slave. We read of a new escape of João, without "Mulato" that before accompanied his name. We read that he had been captured along with Alexandrina in March of 1858. She was doomed to have her life commercialized, was put up for sale, while he returned to his owner, from whom he had escaped once before, but this time, in the company of "a mulatto named José Paulino". In this new advertisement, the physical characteristics of John are again described, with differences from the previous text, being said that João would have: "a little lump in the left eyelid and some blemishes on the side of the face that, before the escape of March of 1856 along with his partner Alexandrina, bore the word - slave." There is no reference to this word, which identified his condition, to be written in general language as before. Was it deliberately "erased"? Was it this the origin of such blemishes that he had on his face, did he maim himself to hinder his identification? The advertisement is again published on May 29 1858, and we do not hear of him anymore.

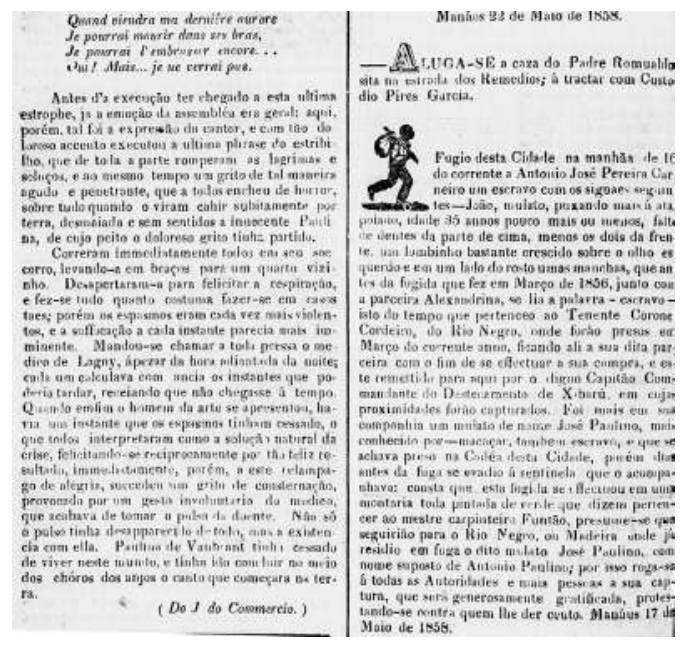

Figure 3: Detail of the last page of May 22, 1858 edition of Estrella do Amazonas, on the right we find the sequel of João's fight for freedom and in another advertisement the escape of the slave (used with permission of the Biblioteca Nacional).

the last verse of a song: "when will come my last sunrise / I may die in my arms / I may kiss you again... / Yes! but... I would not see", that would have caused a great commotion in the audience, including the dramatic death of a listener. 
As of 1870, migrations of northeasterners to the Amazonian region accelerated the disuse of the LGA, is frequently treated as a mere dialect: "unclear, imperfect, shoddy, poor, inelegant, confusing, incapable of expressing universal ideas" (Freire, 2003, p. 27). Its records in journals and government reports are scarce, although important for revealing this movement from the center to the outskirts. After helping render meaning to the Amazonian world and facilitate the communication among Indians, colonizers, missionaries, mestizos and others, the LGA, such as slaves like João Mulato, Alexandrina, and Geraldo, had to escape to try to survive. Fortunately is still alive and today it may teach us, not in the primitive and violent way that was imposed and later fought, but genuinely as a "good speech.”

\section{CONSIDERATIONS AND FINAL POINTS}

Bonsieppe (2001, p. 29) recognizes that the design, or project practice, as being exposed to contradictions, and are frequently used as a domination instrument for political and economic interests. Indeed, it seems to be what happens in many cases of planning and production of printed artifacts and deliberately ignoring the language spoken by the majority of the population. We should not overestimate the potential of social intervention that a graphics project, or the various other forms of visual planning indeed possess. What was aimed to show in this study was what mysteriously is not visible in the printed communication produced in the Amazonian region: another language and also a culture turned invisible. In the 19th century, when printing technology arrives in Brazilian lands, not aimlessly along with the Portuguese Court, the number of typographic enterprises spread all over Brazilian territory would have high dependency on government orders, acting, in many cases, as a spokesperson. The information was the speech rendered in "good" Portuguese, the Falla, the Exposição or the account of official realizations, printed in types, ink and in time. Through these records, the historical narrative of the region has been told, not without criticism or theoretical apparatus to deconstruct repeated fake certainties.

By crossing the objectively summarized narrative of the Língua Geral Amazônica, we aim to reflexively read this history associated to printed culture, so as to be capable of understanding the role of graphics technology, its project, and artifacts in a broader picture. The native people held protagonism, formed the workforce that generated the wealth needed by their colonizer, and were mixed as a minor ingredient in the social blend of the region. The indigenous people were educated to learn customs unrelated to their reality and a language to become part of a more homogeneous system; in this way, many have lost their identity and the belonging of a community. To the civilized, it was enough that their or- 
ders were understood and, mainly, carried out, so to maintain control. When the strategy accomplished its purpose and the weak control was at risk, it was the Portuguese language imposed as the only general language. Although it was not sufficient to silence Nheegatu, here we are, writing in Portuguese an article translated into English to speak of another continent language, the one from the Tupis. The typographic technology translated it in the silence that, however, was uncomfortably audible, marked on the flesh of João Mulato. His story printed in the newspaper, a life inaccurately described in only two advertisements of his escape. His surname was a form of characterizing him, a "Mulato", his age was not clear, he was "around 35 years old". Information composed at the end of the journal Estrella do Amazonas, almost fully taken by the "Official Section".

The great mesh of Amazonian languages was dammed into an imposed general language that expanded and flooded the whole region, threatening the domination of not only of the Portuguese speech.

The Portuguese crown intensified the control in the 18th century, ordered to silence the LGA, with the use of force and compulsory education in the official language, the same printed in journals and editions. Since it was not possible to silence it for good, it was pushed to a marginal place, visible in official documents, in the advertisements in the journals, in João's skin and certainly in the lives of many others. For them, the "good speech" or Nheengatu survived and continues to flow, as well as other indigenous languages ${ }^{6}$, and they are even taught and researched in these institutions called universities. With this critical investigation, we sought to describe what was not present or visible before: an encounter with the silenced speech, or even with the knowledge field named design. We thus intended to turn them, speech and knowledge field, a little more "mestizas" by making them bathe in the mixture of knowledge coming from other places, traditions, languages, and eras. We believe that this is a form of enriching the design field of study, by enlarging its contact with each other and thus become smoother its interests and frontiers.

\section{ACKNOWLEDGEMENTS}

To Faperj (Foundation for Support of Research in the State of Rio de Janeiro) for financial support for the doctorate's research.

6 The city of São Gabriel da Cachoeira, Northwestern Amazonas, turned tukano, baniwa and nheengatu co-official languages in 2002. The location has indigenous people as the majority of the population, being spoken eighteen languages. 


\section{REFERENCES}

Amazonas, Lourenço da Silva Araújo e. (1852). Dicionário Topográfico, Histórico, Descritivo da Comarca do Alto Amazonas. Recife: Typographia Commercial de Meira Enriques.

Bhabha, Homi K. (1998). O local da cultura. Belo Horizonte: UFMG.

Briggs, Asa; Burke, Peter. (2016). Uma história social da mídia: de Gutenberg à Internet. Rio de Janeiro: Zahar.

Bonsieppe, G. (2011). Design, Cultura e Sociedade. São Paulo: Edgar Blücher Ltda.

Briggs, Asa and Burke, Peter. (2006). Uma história social da mídia: de Gutenberg à Internet. Rio de Janeiro: Jorge Zahar Editor.

Bringhurst, Robert. (2006). A forma sólida da linguagem. São Paulo: Edições Rosari.

Buchanan, Richard. (2009). Thinking about design: a historical perspective. Philosophy of Technology and Engineering Sciences, 9. Elsevier.

Burke, Peter. (1995). A Arte da Conversão. São Paulo: Editora da Universidade Estadual Paulista.

Canclini, Nestor Garcia. (2008). Culturas híbridas: estratégias para entrar e sair da modernidade. São Paulo: Editora da Universidade de São Paulo.

Cardoso, Rafael (org.). (2009). Impresso no Brasil, 1808-1930: destaques da história gráfica no acervo da Biblioteca Nacional. Rio de Janeiro: Verso Brasil.

Costa, Danilo Padilha Pacheco. (2016). A História da Província do Amazonas na obra de Lourenço da Silva. Anais do Simpósio X Simpósio identidades e linguagens da/na Amazônia Sul-Ocidental.

Flusser, Villém. (2007). O mundo codificado: por uma filosofia do design e da comunicação. São Paulo: Cosac Naify.

Forty, Adrian. (2007). Objetos do desejo - design e sociedade desde 1750. São Paulo: Cosac Naify.

Freire, José Ribamar Bessa (coord.). (1994). Amazônia colonial (1616-1798). Manaus: Editora Metro Cúbico.

Freire, José Ribamar Bessa. (2003). Da Língua Geral ao Português: para uma história dos usos sociais das línguas na Amazônia (Doctoral dissertation). Universidade do Estado do Rio de Janeiro, Rio de Janeiro.

Garcia, Etelvina. (2005). Amazonas, notícia da história: período colonial. Manaus: Norma Editora.

Latour, Bruno. (2014). Um Prometeu cauteloso? Alguns passos rumo a uma filosofia do design (com especial atenção a Peter Sloterdijk). Agitprop revista brasileira de design, $6(58)$.

Lima, Guilherme Cunha; LIMA, Edna Lucia Cunha; MARTINS, Fernanda de O. (2014). Apontamentos para uma História do Design Gráfico no Brasil - o caso do Pará - Levantamento das empresas tipográficas do Pará entre 1820 e 1850 . Anais do $6^{\circ}$ Con- 
gresso Internacional de Design da Informação.

Margolin, Victor. (2014). A política do artificial: ensaios e estudos sobre design. Rio de Janeiro: Record.

Navarro, Eduardo de Almeida. (2012). O último refúgio da língua geral no Brasil. Estudos Avançados, 26(76).

Pereira, Rômulo do N.; MEDEIROS, Ligia. (2016). Subsídios para uma história do design gráfico no Brasil: a primeira tipografia do Amazonas (1851-1866). Anais do $12^{\circ}$ Congresso Brasileiro de Pesquisa e Desenvolvimento em Design.

Pinheiro, Maria Luiza Ugarte. (2015). Folhas do Norte: letramento e periodismo no Amazonas (1880-1920). Manaus: Edua.

Rizzini, Irma. (2002). Domesticar e Civilizar: Crianças indígenas e o ensino de ofícios no Norte do Brasil Imperial . Anais do II Congresso Brasileiro de História da Educação.

Rodrigues, Aryon D. (2003). Aspectos da história das línguas indígenas da Amazônia. Sob o signo do Xingu. Belém: UFPA / IFNOPAP.

Rodrigues, Aryon D. (2005). Sobre as línguas indígenas e sua pesquisa no Brasil. Ciência e Cultura, 57(2).

Sampaio, Patrícia Maria Melo. (1997). Os fios de Ariadne: tipologia de fortunas e hierarquia sociais em Manaus: 1840-1880. Manaus: Editora da Universidade do Amazonas.

Sampaio, Patrícia Melo. (2002). Nas teias da fortuna - acumulação mercantil e escravidão em Manaus. Mneme revista de humanidades, 3(6). 
